\title{
Study Amendment of Post-Field Classification of Illegal Gold in Kolaka Regency, Southeast Sulawesi Province
}

\author{
Alfan eka suardana ${ }^{1}$ Fuad Muhammad $^{2}$ \\ ${ }^{1}$ Magister Program of Environmental Science, School of Postgraduate Studies, Diponegoro University, Semarang - Indonesia \\ ${ }^{2}$ Department of Environmental Engineering, Faculty of Engineering, Diponegoro University, Semarang - Indonesia
}

\begin{abstract}
Illegal mining activities in the kolaka regency of Southeast Sulawesi province is one of the mines whose location is in the conservation area of nature tourism park. Mining by means of dredging with an average depth of up to 15 meters and indiscriminate stockpiling after mining, using mercury chemicals (hg) so make the land damaged and unproductive, changes in the landscape and damage the physical properties of the soil that makes the soil $\mathrm{pH}$ becomes sour, so as to make soil quality low, dust texture increased and soil compaction that makes soil chemistry decreased, so can not support the growth of plants around the mine, the occurrence of heavy erosion and loss of top soil. the mining area reaches 50 hectares which damages the soil quality and removes vegetation around the area.
\end{abstract}

Keywords: illegal mining, mercury (hg), vegetation.

\section{INTRODUCTION}

Indonesia is a country rich with some potential natural resources. The natural wealth makes Indonesia as one of the countries that have a large mining area. Mining land is spread across various islands in Indonesia. The natural wealth is explored to meet human needs. Some problems arise due to mining activities ranging from the emergence of various diseases due to decreasing environmental quality and the extinction of some flora and fauna that became the character of the local area. The existence of mining businesses contributes substantially to state revenues but there are also illegal mining or Unlicensed Mining (UM) which is detrimental to the state and also destroys the environmental ecosystems surrounding the mine. The contribution of the mining sector to forest degradation in Indonesia reaches $10 \%$ and now accelerates to two million hectares per year [1].

UM is an activity of Unlicensed Gold Mining conducted by some communities and the other elements; Unlicensed Gold
Mining is a "label" given by the State to mining actors who are not licensed by the government as holders of state control over mining materials. Regardless of whether mining is the people doing mining activities based on customs, or those who only "gamble" the fate of minerals, it will still hold the label UM if it does not get permission [2] .

Considering that UM activities do not apply good mining practices and are almost untouchable, while on the other hand non-renewable materials and in its potentially destructive (potential polluter) business, then are the negative impacts that not only harm the Government, but also the wider community and future generations. Environmental damage, waste of mineral resources, and moral decline are examples of negative impacts that are detrimental to the Government, the wider community and future generations. [2]

One form of secondary gold mining business is gold mining located in Unggulaka Village, Kolaka Regency, Southeast Sulawesi Province. Gold mining in Unggulaka

* Corresponding author: alfanekasuardana@gmail.com 
Village is located at $3^{\circ} 56^{\prime} 08.9$ "S $121^{\circ} 35^{\prime} 50.5^{\prime \prime}$ E Kolaka Regency from Kendari City, Southeast Sulawesi Province, taking a trip using \pm 4 hours to Kolaka Regency and heading to the mine site traveling $\pm 1-2$ hours walk. The area of gold mining in the area in Unggulaka Village reaches 5 Hectares (Ha) at every point and mining in the area there are more than 50 mining points. The mining location is the Mongolo Nature Park conservation area. Mining activities in Ungguolaka are carried out in groups of 5 - 10 people at each point of mining. The people who mine are from Kolaka Regency or from outside the area such as from Kendari City even from outside the Southeast Sulawesi Province.

Every day mining activities in the Mongolo Nature Park conservation area can produce 10-30 grams of gold at each point . Gold mining in the Kolaka Unggulaka District area is a type of secondary gold mine, so miners do artisanal techniques carried out on the river coast. This mining activity can be classified as illegal mining because it does not have a mining permit from the Kolaka District Government.

These uncontrolled illegal mining activities will cause environmental impact problems at the mine site. Communities that make soil excavations that can damage the environment by using tools such as crowbars, hoes, water pumps to destroy dense soil and which are harmful to the environment and miners are the miners using chemicals such as Mercury ( $\mathrm{Hg}$ ).

The mining activities of precious minerals from the earth's layers have been long-lasting, over a period of 50 years; the basic concept of management is relatively unchanged, changing only the scale of activity. The mechanism of mining equipment has caused the mining scale to become larger and more damaging to the environment. The development of management technology causes the extraction of low grade ore to become more economical, so that the more extensive and deeper the achievement of the layer of the earth far below the surface. This causes mining activities to have enormous and important environmental impacts. The impact of mining activities has a very significant impact, especially in the form of surface water and ground water pollution [4] .

Based on government regulation or PP No. 27 Year 1980, the excavation material in Indonesia is divided into 3 groups, namely: Group A (strategic excavation materials, for example: petroleum, natural gas, coal, nickel, tin, etc.), Group B (vital minerals, for example: copper, gold, iron, etc), and Group C (nonstrategic and non-vital, for example: phosphate, gemstone, benthonic, quartz sand, granite, sand, limestone, marble, etc.) [1]

Manan (1976) in Asmayannur (2012) stated that basic vegetation is an important component in forest communities because it supports the life of other plants. If gold mining activities continue to be done, will have a major impact on the environment and plants in the mining area [19].

The ex-mining land reclamation program is a mandatory program that must be done by every private and non-private company, where the regulation of mining reclamation obligation is regulated by law or UU No. 4 Year 2009 article 96 and bound by legislation in lieu of law or Perpu No.78 Year 2010 article 2 paragraph 1 on Reclamation Post Mine. Mining is done to extract mining materials such as coal, gold, tin, nickel and others. Different mining systems also affect different environmental damage as well. Mining can also affect the performance of the hydraulic function in the soil, and also can decrease the soil productivity level [3] (Patiung, 2011).

The soil is vital for all life on earth because the soil supports plant life. Soil and groundwater are the starting point of the life of the food chain. Physically can be seen from the opening of a large enough land and changed into a barren land of desert containing tailings. By chemical known from pollution of water, soil and vegetation resulting from the use of harmful substances such as mercury. Biologically can be seen from the loss of vegetation and organism associations [12].

This in case of pollution in agricultural areas that are continuously deposited on agricultural land in the long run can reduce the productivity of crops and reduce the quality of agricultural products, and cause toxins in various agricultural and livestock products that bring negative impacts to humans who consume them [10].

Although considered to be the triggers of an environmental degradation event, the most serious threat of them turns out to be mercury $(\mathrm{Hg})$ contamination. Mercury in the effort to separate the gold from the carrier material then mercury mixed with wastewater then pollutes the ground water and river. Even in 2008 artisanal mining was considered one of the ten causes of the worst and most severe pollution in the world [5]. Mercury froze at $-38.9^{\circ} \mathrm{C}$ and boiled at $357^{\circ} \mathrm{C}$ [9]

\section{Problems and Methods}

This study aims to determine the physical properties of soil chemistry on post mining land and to know the level of soil damage in the vicinity of post mining sites. So in the end 
knowledge of physical properties of soil chemistry and postmining soil quality can be as basic information to arrange rehabilitation plan and stop illegal mining.

\subsection{How mercury $(\mathrm{Hg})$ works}

For example small-scale gold mining or gold mining people. Processing of ore is done by amalgamation process where mercury $(\mathrm{Hg})$ is used as gold binder. In the traditional gold amalgamation process conducted by the population, mercury can be released into the environment at the washing and leaching stage.

In the washing process, waste that is generally still containing mercury is discharged directly into water bodies or on the ground. This is because the mercury is mixed / split into fine grains that are difficult to separate in the milling process that is done simultaneously with the amalgamation process, so that in the washing process, mercury is carried in the waste/tailings. [6].

The mercury metal is identified as one of the elements with high toxicity properties and the ease of undergoing transformation into a more toxic form [7]. Mercury endangers human life through the process of food chains. The mercury in the soil will be absorbed by the plant and then biomagnifications process occurs. [8] Contamination of heavy metals in the soil, one of which mercury can be remedied by biological, chemical, or physical remediation.

\subsection{The Effect of Land Permeability on Mercury Content on Land}

The soil has a permeable property where water flows through the pore spaces that exist between the grains of the soil. Permeability demonstrates the ability of the soil to pass water structures and textures as well as other organic elements also take part in raising the rate of inflation and lowering the rate of water. Soil texture is one of the physical properties of soil, as well as permeability. Permeability can affect soil fertility.

Different permeability with more drainage refers to only water flow processes, permeability may include how water, organic materials, mineral materials, air and other particles carried along with water will be absorbed into the soil.

Measurements of soil permeability are carried out by measuring the volume of water coming out on the soil samples used. In sampling, it takes an iron tube about $40 \mathrm{~cm}$ long to be immersed in the soil. Once immersed approximately at a depth of $30 \mathrm{~cm}$, the iron tube is removed. Soil in the iron tube that will be sampled and tested in the soil mechanics laboratory. The permeability value is expressed in units of $\mathrm{cm} / \mathrm{sd}$. To determine the permeability value $(\mathrm{k})$ in the laboratory, the tool used is a permeater. [6]

\subsection{Mercury in rocks}

Mercury is rarely encountered as native mercury in nature and usually forms the minerals of cinnabar or mercury sulphide $(\mathrm{HgS})$. Mercury sulphides are formed from hydrothermal solutions at low temperatures by means of cavity filing and replacement. Mercury is often associated with other sulphide metal deposits, such as $\mathrm{Au}, \mathrm{Ag}, \mathrm{Sb}, \mathrm{As}, \mathrm{Cu}, \mathrm{Pb}$ and $\mathrm{Zn}$, so that in mineralized regions of the root gold usually mercury content and some other heavy metals [11].

The average abundance of mercury and some heavy metals in un-mineralized rocks can be seen in Table 1. 
Table 1. Average abundance of some heavy metal elements in various rock types

(Source: Field Geologists' Manual)

\begin{tabular}{|c|c|c|c|c|c|}
\hline \multirow{2}{*}{ Element } & \multicolumn{5}{|c|}{ Average abundance (ppm) } \\
\hline & basal & granodioit & granite & splinter & limestone \\
\hline $\mathrm{Au}$ & 0.004 & 0.004 & 0.004 & 0.004 & 0.005 \\
\hline $\mathrm{Hg}$ & 0.1 & 0.07 & 0.04 & 0.05 & 1 \\
\hline $\mathrm{Ag}$ & 0.08 & 0.08 & 0.08 & 0.5 & 0.05 \\
\hline As & 2 & 2 & 2 & 15 & 2.5 \\
\hline $\mathrm{Cu}$ & 100 & 30 & 10 & 50 & 15 \\
\hline $\mathrm{Pb}$ & 5 & 15 & 20 & 20 & 8 \\
\hline $\mathrm{Zn}$ & 100 & 60 & 40 & 100 & 25 \\
\hline $\mathrm{Cd}$ & 0.2 & 0.2 & 0.2 & 0.2 & 0.1 \\
\hline
\end{tabular}

Nurthjahya (2008) in his research stated that succession on tin mining land is running very slowly. It can be concluded that the former mining area suffered a lot of

\subsection{Vegetation of land}

In the former gold mining area there is usually a natural succession. The early state of secondary forest which later became the expanse of sand due to gold mining. Over time, the land in the form of expanse of sand slowly overgrown by grass or pioneer plants. [12] Suggested that secondary succession is a pattern of changes in vegetation due to environmental disturbance, which causes the area not to be vegetated to be gradually regenerated [13].

Manan (1976) in Asmayannur (2012) stated that basic vegetation is an important component in forest communities because it supports the life of other plants. If gold mining activities continue to be done, will have a big impact on

Odum (1971) suggests that communities to reach climax will vary in different ecosystems. Furthermore, it is said that community turnover tends to change the physical environment, thus becoming a suitable habitat for other communities until the biotic balance is reached [14].

Soerianegara and Indrawan (1988) states that if the rainforest is damaged by nature or humans, the secondary succession that occurs usually begins with the vegetation of grass and shrubs. If the condition of the soil is not suffered much damage, then after 15-20 years there is a young secondary forest, and after 50 years old secondary forest occurs which will gradually reach climax [15]. damage, so the natural succession on the former mining land goes very slowly to return climax [16]. Soils containing many $\mathrm{H}+$ ions are acidic, while soils containing lots of $\mathrm{OH}$-ions are alkaline [17]. $\mathrm{pH}$ measurements are important because plant life is largely determined by soil $\mathrm{pH}$, because of the low pile of plants causing soil temperatures to rise [18].

\section{Conculsion}

Based on the existing problems, when doing the mining we should anticipate by reducing the use of mercury $(\mathrm{Hg})$ and excavation of the soil prior to mining should the top soil be stored and not mixed function to recover after post mining.

\section{References}

1. Sitorus, S. R. P Dan L. N. Badrisoil Characteristics And Vegetation Of Degraded Land Post Tin Mining As Well As Rehabilitation Technique For Revegetation Purposes. Prosiding Semiloka Nasional 22-23 December 2008.

2. Trisna Anjani, "Social Impact Of Unlicensed Gold Mining (Chests) In Sorik River Village Kuantan Downstream Sub-District Kuantan Singingi District”, Vol. 4 No. 4 - 2017. 
3. Patiung, O., N. Sinukaban, S.D. Tarigan, and D. Darusman. 2011. The Effect of Reclamation Age of Coal Mine on Hydrological Function, Journal of Hydrolitan Vol. 2 No. 2 (60-73).

4. Arif, I., Total Mine Planning As An Effort To Solve Mining Environment Problems, Sam Ratulangi University, Manado, 2007.

5. Ericson, B ,Et Al, 2008

6. Haning Cihintya Rahni , Related Factors With Mercury Content (Hg) On Land Place Property Around The Traditional Gold Mining Location (Case Study In Jendi Village, Selogiri District, Wonogiri Regency, Central Java Province). Volum 1, Nomor 2 , Hal 973- 982, 2012.

7. Mudyazheza, S,. And Kanhukamwe, R. Environmental Monitoring Of The Effeects Of Conventional And Artisanal Gold Mining On Water Qucilty In Nguwabalozi River, Southern Zimbabwe. Jurnal Of Environmental Monitoring And Analysis, 2, Halaman 123- 127, 2014.

8. Wang J,. Feng X,. Anderson, C., Remediation Of Mercury Contaminated Sites - A Riview. Jurnal Of Hazacdoos Materials . 221 -222 Volume 1-18, 2012.

9. Stwertka., A. Guid To The Elements Oxford Universty Press, New York, Hal 240, 1998.

10. Yunita Miu, Analysis Of Mercury Content ( $\mathrm{Hg}$ ) On Landscape In Taluduyunu Village Buntulia District District Of Pohuwato. 2013.

11. Bambang Tjahjono Setia Budi, Mercury Distribution Because Of Gold Mining Businesses In Sangon Region, Kulon Progo Regency, D.I. Yogyakarta . 2005.
12. U. Nur Isnaniarti, Wiwik Ekyastuti, Hanna Artuti Ekamawanti, Success Of Vegetation On Land Used Gold Mining In The District Monterado District Bengkayang, Vol 5 (4) : 952 - $961,20017$.

13. Sastroutomo, S.,. Ekologi Gulma, PT. Gramedia Utama Pustaka, Jakarta. 1990.

14. Odum, E.P.. Fundamentals Of Ecology. W.B Sanders Company. Philadeliphia-London-Toronto, 1971.

15. Sorianegara, I., Dan A. Indrawan,. Ekologi Hutan Indonesia, Fakultas Kehutanan Institut Pertanian Bogor, Bogor, 1988.

16. Nurthjahya, E.. Revegetasi Lahan Pasca Tambang Timah Dengan Beragam Jenis Pohon Lokal Di Pulau Bangka. [Tesis] Bogor: Sekolah Pasca Sarjana, Institut Pertanian Bogor, 2008.

17. Lici Astuti, Nursyahra And Lince Meriko, Composition And Structure Of Basic Vegetation On The Location Of Sold Gold Mining In Nagari Mountain Medan Sub District Sitiung District Dharmasraya

18. Suin, N.M. Ecological Method. Padang: Andalas University Press, 2002

19. Asmayannur, I. 2012. Analysis of Basic Vegetation Under Gold Teak (Tectona grandis L.) and Jati Putih (Gmelina arborea Roxb.) At Andalas University Campus. Andalas University scientific journal. 